INDEPENDENT JOURNAL OF MANAGEMENT \& PRODUCTION (IJM\&P)

http://www.ijmp.jor.br

v. 12, n. 4, May-June 2021

ISSN: 2236-269X

DOI: 10.14807/ijmp.v12i4.1352

\title{
QUALITY OF SERVICES: AN APPLICATION WITH CUSTOMER COMPLAINT DATA FROM A TELECOMMUNICATION COMPANY
}

\author{
Jorge Alberto Achcar \\ University of São Paulo, Brazil \\ E-mail: achcar@fmrp.usp.br \\ Daniel Marcos de Godoy \\ Universidade de Araraquara, UNIARA, Brazil \\ E-mail: danielmarcosgodoy@hotmail.com
}

Submission: 5/27/2020 11:33:01 AM

Revision: 7/3/2020 3:57:30 PM

Accept: 7/14/2020 10:14:23 AM

\section{ABSTRACT}

The evaluation of the service quality standard of a telecommunication company using statistical process control (SPC) methods is the main goal of this paper. The study used a dataset collected from January 2018 to November 2019 associated with monthly and weekly customer complaint counts due to the technical services provided by the company. Multiple linear regression models with the count data transformed to a logarithmic scale and Poisson regression models with the original count data detected some significant factors affecting the weekly/monthly complaint counts. In addition, forecasts of future complaint counts based on the statistical models could be of interest for the company to plan the number of technicians in different sectors at different times of the year leading to improvements in the service provided by the telephone company.

Keywords: quality of services; complaint counts; multiple linear regression models; Poisson regression models; statistical process control 
DOI: 10.14807/ijmp.v12i4.1352

\section{INTRODUCTION}

The great technological advance, especially in the last decades, allowed telecommunications companies to expand substantially their markets in economic terms. Despite this advance, usually there are many everyday problems in a telecommunication company, especially in customer services with many complaints about the provided services. The present study has as main goal, the analysis of service data and complaints from external customers of a telephone company, investigating service failures, discovering factors that affect the complaint counts and proposing suggestions for improvements, especially in the technical service area. Studies on customer complaints are of great interest in companies in different sectors (Anderson, Fornell \& Mazvancheryl, 2004; Claro et al., 2014; Coelho et al., 2016; Fornell \& Wernerfelt, 1987; Luo, 2007, 2009; Romani, Grappi \& Dalli, 2012; Singh \& Wilkes, 1996; Singh, 1988). The research developed in a telecommunications company, which operates in the central region of the São Paulo state.

The main goal of this study is to discover the significant factors affecting the increase in repair complaints in a medium-sized municipality in the central region of São Paulo state, Brazil, related to broadband services. The company in the city has been operating since 2014 with the Optic Fiber product with VOIP, Broadband and DTH/IPTV TV products. The Broadband product is the most commercialized due to the high speed of the optical fiber with almost no signal loss.

However, the Broadband product, as the most commercialized one, is also the one with the largest number of customer complaints. Some factors could affect the great variability in the complaint counts related to the Broadband services. These factors are into two classes: causes associated with customers (customer cancels a visit, customer refuses a visit, customer found with different complaints, customer equipment) and technical causes (Table 1).

Figure 1 shows the plots of the monthly percentages of complaints from the company customers for the period from January 2018 to November 2019. Table 2 shows the complaint counts corresponding to that period. Figure 1 and Table 2 show that the monthly percentages of complaints remain reasonably high associated with different causes of complaints associated with customers until July 2018 (month 7). From this month, there is a sharp drop. From month 8 of 2018, there is a tendency for the number of complaints to increase until the month 9 of 2019 (September 2019), when the number of complaints associated with the causes due to customers starts to decline. 
DOI: $10.14807 /$ ijmp.v12i4.1352

Regarding technical causes, it is observed that the number of complaints remains approximately constant with a decline at the end of the time series (last months of 2019), an indication of improvement in the technical services provided by the company.

Table1: Technical causes of customer complaints

OTB connection: it is a problem inside the Optical Transmission Box (OTB). The OTB's are composed of 8 or 16 ports (if they are double counting boxes) and the connector can present problems. In rare cases, the box own splitter may be with malfunction. This type of occurrence affects the total functioning of the customer's products.

Modem exchange: it is about the equipment itself. The reasons may be different. However, when the same type of equipment has too many problems, there is a batch of equipment with problems. For reasons other than this, the equipment itself for some reason does not synchronize the signal.

- Customer optical cord: a transition fiber comes out of OTP (Optical Transmission Point) box. It is very thin and by any sharp movement (broom beating, pets or children), is easily damaged.

Internal component exchange: it is the coaxial cable or coaxial cable connector or even the signal splitter that can present problems. Coaxial cable is the same cable used in antennas. The connector is also the same as that used for antenna cables. Signal splitter sends signal from the main point to more rooms in the house / apartment / company.

Unconfigured TI service: it is a type of error in the firmware update. The equipment updates itself at systemically determined periods. Sometimes the download fails and causes an error in the equipment where the synchronism is lost and the signal does not return, requiring a row back or even changing the equipment.

Bid customer OTB: the external fiber that for some reason is broken and needs to be changed. It may be a breakup due to collision with a high vehicle (cargo truck) or even theft.

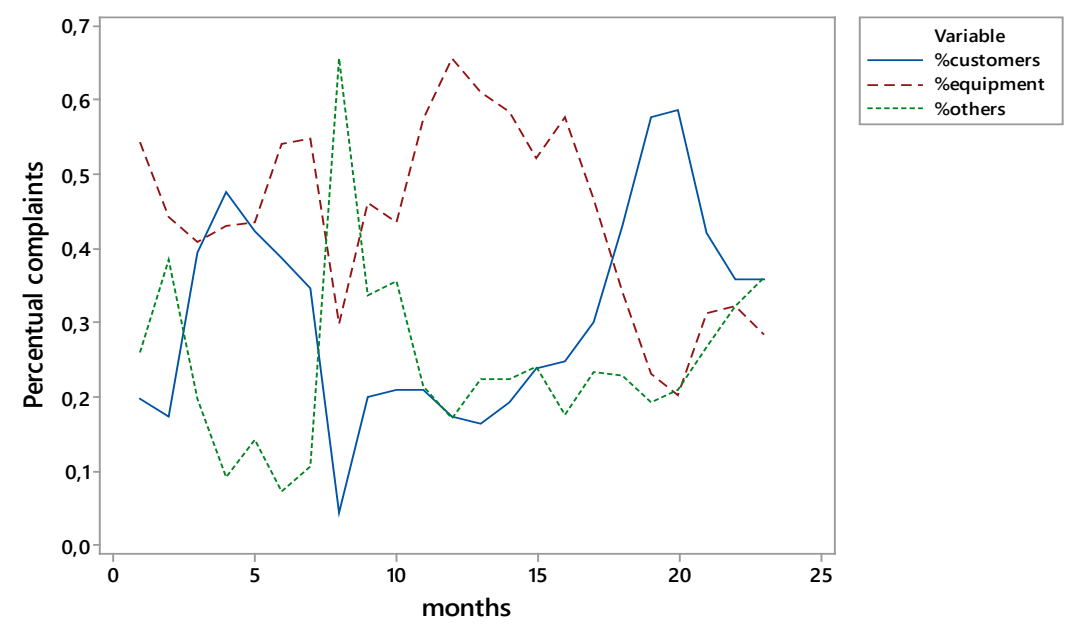

Figure 1: Complaint percentage time series due to different causes 
INDEPENDENT JOURNAL OF MANAGEMENT \& PRODUCTION (IJM\&P)

http://www.ijmp.jor.br

v. 12, n. 4, May-June 2021

ISSN: 2236-269X

DOI: 10.14807/ijmp.v12i4.1352

Table 2: Monthly percentages of complaints due to various causes in the period from January 2018 to November 2019

\begin{tabular}{|rrrlll|}
\hline Month & Year & Complaints & \%customers & \%equipment & \%others \\
1 & 2018 & 522 & 0.197318 & 0.544061 & 0.258621 \\
2 & 2018 & 440 & 0.172727 & 0.443182 & 0.384091 \\
3 & 2018 & 325 & 0.393846 & 0.409231 & 0.196923 \\
4 & 2018 & 379 & 0.477573 & 0.430079 & 0.092348 \\
5 & 2018 & 468 & 0.423077 & 0.435897 & 0.141026 \\
6 & 2018 & 458 & 0.386463 & 0.541485 & 0.072052 \\
7 & 2018 & 475 & 0.345263 & 0.549474 & 0.105263 \\
8 & 2018 & 529 & 0.043478 & 0.298677 & 0.657845 \\
9 & 2018 & 590 & 0.200000 & 0.462712 & 0.337288 \\
10 & 2018 & 749 & 0.209613 & 0.435247 & 0.355140 \\
11 & 2018 & 531 & 0.209040 & 0.576271 & 0.214689 \\
12 & 2018 & 533 & 0.172608 & 0.656660 & 0.170732 \\
1 & 2019 & 523 & 0.164436 & 0.611855 & 0.223709 \\
2 & 2019 & 544 & 0.191176 & 0.584559 & 0.224265 \\
3 & 2019 & 580 & 0.237931 & 0.522414 & 0.239655 \\
4 & 2019 & 568 & 0.248239 & 0.577465 & 0.174296 \\
5 & 2019 & 833 & 0.301321 & 0.465786 & 0.232893 \\
6 & 2019 & 733 & 0.429741 & 0.342428 & 0.227831 \\
7 & 2019 & 865 & 0.576879 & 0.230058 & 0.193064 \\
8 & 2019 & 738 & 0.588076 & 0.201897 & 0.210027 \\
9 & 2019 & 688 & 0.421512 & 0.312500 & 0.265988 \\
10 & 2019 & 797 & 0.357591 & 0.321205 & 0.321205 \\
11 & 2019 & 764 & 0.357330 & 0.282723 & 0.359948 \\
\hline
\end{tabular}

\subsection{Goals of the study}

The main goals of this study are:

- To find from different statistical methods, possible factors of the company's technical services that significantly affect the complaint counts for the services provided.

- To get appropriate models in the presence of the covariates mentioned above for the complaint counts to be used by the company to improve the performance of the technical services.

- To get prediction failure counts that can assist the company to make better decisions.

The article follows: section 2 presents a brief summary of service quality; section 3 presents a review of the literature on customer quality service complaints; section 4 presents some remarks on statistical process control; section 5 presents the methodology and the data analysis; finally, section 6 presents a discussion of the obtained results and concluding remarks.

\section{QUALITY OF SERVICES}

In telecommunications company services, customers in general expect good quality of service and technical assistance. In this sense, Kotler and Armstrong (2003, p. 475) point out that “Attracting and retaining customers can be a difficult task. In today's world, even in third 
DOI: 10.14807/ijmp.v12i4.1352

world countries, customers have at their disposal a wide variety of products and brands, prices and suppliers to choose their products”. In this way, quality of service or customer service is of great importance for a company, since through good service, companies value their image, attract and retain customers.

In another study, Chiavenato (2007, p. 216) establishes that "the customer is essential for the company to remain in the market and customer service is one of the most important aspects of the business". In a telecommunications company, this relates to a good provision of technical services. It is interesting to emphasize that a company's foundation relates to the customer. Albrecht and Bradford (1992, p. 17), states that,

- The customer is the most important person in any type of business.

- The customer does not depend on the company. The company depends on the customers.

- The customer does not interrupt our work. It is the purpose of our work.

- The customer does us a favor when he enters in the company. We are not doing any favor waiting for the customer.

- The customer is an essential part of our business - not a disposable part.

- The customer does not just mean cash in the cash register. He is a human being with feelings, who needs treatments with all respect.

- The customer deserves all possible attention and courtesy.

- He is anybody's blood. He is the one who pays our salary.

- Without the customer, we would close our doors.

\section{LITERATURE REVIEW ON CUSTOMERS COMPLAINTS}

Claro et al. (2014) point out that consumer complaints affect the company's market value and common sense suggests that a negative impact relates to customer complaints. Low levels of complaints allow companies to increase market value, while high levels of complaints increase damage to the market value. It is important to note that consumers today have increasing access to the Internet where negative or positive information reports at any time. 
Usually customer frustrations or unmet expectation spreads through social media where complaints about a product or service reach a very large number of consumers, which can affect a company's reputation (Martins \& Julio, 2013; Coelho et al., 2016; Anderson et al., 2004). It is important to point out that consumers increasingly use social networks to conduct research on the quality certification of a service or product, before making the purchase (Pimentel et al., 2012).

Some studies show that dissatisfaction can result in very negative images for companies (Matos \& Rossi, 2008; Singh \& Wilkes, 1996; Trusov, Bucklin \& Pauwels, 2009), or can lead to complaints in public agencies (Singh, 1988). In many cases, it is possible for regulatory agencies such as ANATEL, the regulatory agency that deals with all telecommunication problems in Brazil, to maintain public records of complaints and assess the performance of companies specially linked to public services based on the levels of consumer complaints (Luo, 2009; Winchester et al., 2008).

Thus, a company can become vulnerable to the level of complaints that influence the market value of the company in a direct linear relationship (Luo, 2007, 2009) or in a non-linear relationship. Some studies have analyzed the behavior and background of complaints (Richins, 1983; Singh \& Wilkes, 1996) and the direct linear effect on the company's market value (Chevalier \& Mayzlin, 2006; Goldenberg et al., 2007; Mittal et al., 1998; Romani, Grappi \& Dalli, 2012).

Sousa (2011) emphasizes that competitiveness between companies, based on attracting and retaining customers, has been increasingly encouraged. Customer satisfaction levels has become a crucial task for the success and growth of companies, which must be able to guide their activities towards the market, thus generating widespread customer satisfaction. The satisfaction survey conducted in that study allowed the identification of some aspects to improve the service. In this process also was studied the existence of non-linear relationships.

Kotler (1998, p. 59) states that, "to understand the process of relationship with the consumer, one must first examine the process involved in its attraction and maintenance". According to this author, the great challenge for companies is to turn potential consumers into customers. Many consumers can become inactive or leave the company for some reasons, among them, dissatisfaction, and the company must somehow reactivate dissatisfied consumers through new specific strategies and tools to develop greater satisfaction and trust for the 
DOI: 10.14807/ijmp.v12i4.1352

customers. For Mahfood (1994, p.1), "most people who serve the public in some way, whether they are salespeople, service installers, professionals, or even public servants, to a certain extent, should try to satisfy the customers they encounter".

Fornell and Wernerfelt (1987) developed a mathematical model of the effects of complaints management as a defensive marketing tool. These authors emphasize that whenever the loss of revenue is greater than the cost, if a sufficiently large proportion of claimants are convinced to remain customers, complaints should be encouraged to improve the product or services.

Some studies related to customer complaints consider questionnaires sent to customers. In this way, Portaluppi et al. (2006) studied customer service and satisfaction in an agricultural company based on data obtained by a questionnaire. From a data analysis (descriptive statistics and graphs), it was detected that in relation to the service, despite the company serving its customers well, there are some needs, such as wishes and habits pointed out by the customers. With the obtained results from the study, it was possible to establish strategies to win back customers with a lower degree of satisfaction. Thus, in view of the obtained results, although the company had many positive responses from the customers, the authors indicated some suggestions and recommendations to improve the service. With the obtained results from the study, it was possible for the company to strengthen its image in the market, because through the obtained results, it was possible to correct flaws that could harm the business operations.

In many studies, it is possible to analyze large amounts of complaint data reported daily and recorded in company databases to discover time trends, discover possible factors that may imply in large numbers of complaint counts and make predictions, as is the case of the present study.

\section{STATISTICAL PROCESS CONTROL}

Statistical Process Control (SPC) is a set of procedures adopted to assess, maintain and improve quality standards at the various stages of manufacture. These process control procedures guarantee quality in an economical way. The control techniques that define these procedures help to evaluate process patterns in terms of dimensions and rework, as well as to study the behavior of the processes, that is, to help to maintain appropriate quality standards.

If it is not appropriate, corrective actions return the process to the desired standard, helping to embed quality in the product and then exercising control over the process. Gimenes et al. (2013) point out that the use of statistical methods has shown its efficiency in the control 
DOI: 10.14807/ijmp.v12i4.1352

of production processes showing whether the product is within a degree of compliance or not, based on an established control parameter.

Melo et al (2019) report that SPC is a preventive methodology to compare results with an already established standard and, through additional statistical techniques, to eliminate or at least control extra variability. In all production processes, disturbances occur, regardless of the exceptional quality design and/or maintenance. Melo et al (2019) citing Montgomery (2012), explain that the variability is:

a) Random or common causes of variation: they are intrinsic to the process and arise, in general, from incorrectly adjusted or controlled machines, operational failures or defective raw material. They are generally difficult to perceive and are part of a constant system of variations. However, the process can still work without causing defective products. A process that has only random causes is under control.

b) Attributable or special causes of variation: they have much greater sources of variation than natural variability, and usually represent an unacceptable level of process performance. The process that contains them is out of control; we need to identify and correct the attributable causes.

According to Carvalho and Paladini (2005), the concept of statistical process control (SPC) is that processes with less variability enable better levels of quality in production results, in addition to reducing costs. On the other hand, Montgomery (2012) states that many organizations believe that it is difficult and costly to provide products with the same quality characteristics to the customer.

\section{METHODOLOGY AND DATA ANALYSIS}

Weekly counts of service complaints provided by the company are considered for the study (Figure 2) consisting of a time series of 119 weeks (between January 1, 2018 and April 30, 2020). Figure 2 shows that there is apparently a temporal growth in complaint counts and some seasonality.

Associated with the weekly counts, there are several covariates: customer causes (customer cancels visit, customer refuses visit, customer found with various complaints, customer equipment) and technical causes (modem exchange count, customer optic cord count, internal component exchange count, unconfigured TI service count, customer OTB bid count), month and year. 


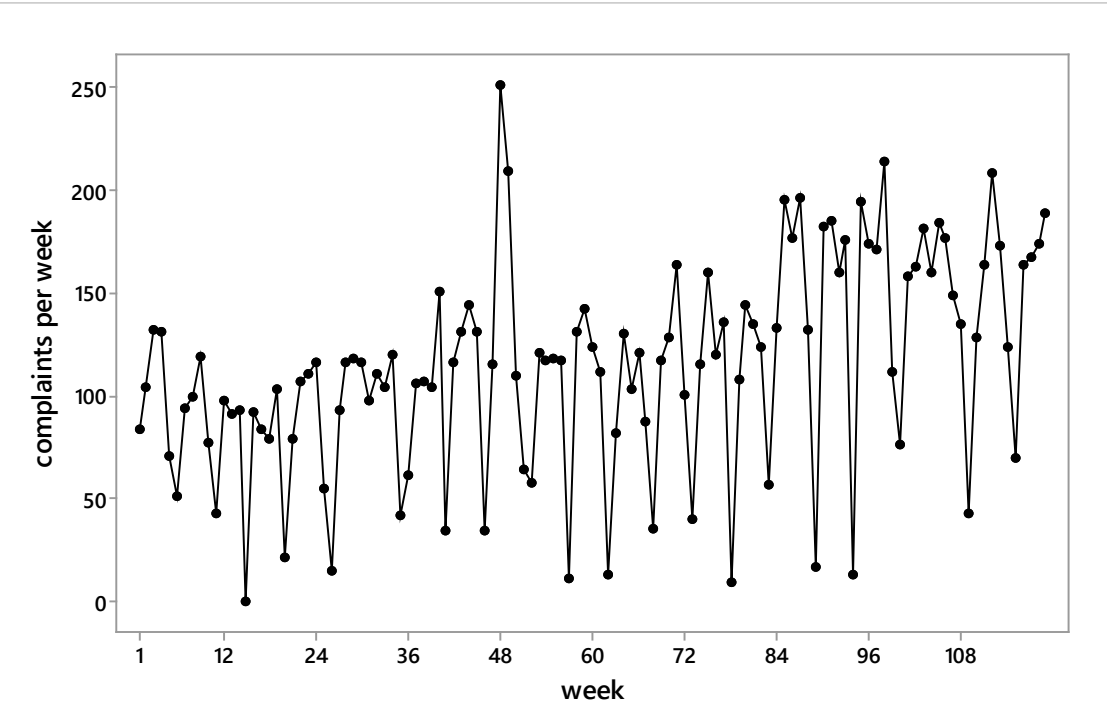

Figure 2: Weekly complaint count series (2018/2019)

In the statistical data analysis it was considered $n=117$ observations, since two observations with missing covariate information were deleted from the initial sample of size 119. The dispersion diagrams presented in Figure 3 show that apparently the covariates due to causes associated with customers given by customer refuses to visit and customer equipment and the covariates associated with technical factors given by OTB connection, OTB customer bid, unconfigured TI service, internal component exchange and modem exchange affect the complaint counts. The covariate customer optical cord apparently has no effect on the response, that is, an increase of complaints due to the technical customer optical cord does not lead to an increase in the number of weekly complaints.

\subsection{Use of a linear regression model with normal errors for the weekly complaint counts transformed to the logarithmic scale}

Although the data are weekly counts, a first statistical analysis assumes the response data transformed to a logarithmic scale, that is $\log ($ complaint count), to verify the possible association between each covariate with the response complaint count in each week using usual linear regression models for continuous data assuming a normal distribution for the errors (Montgomery \& Runger, 2011). 
DOI: 10.14807/ijmp.v12i4.1352

(a) Covariates associated with customers

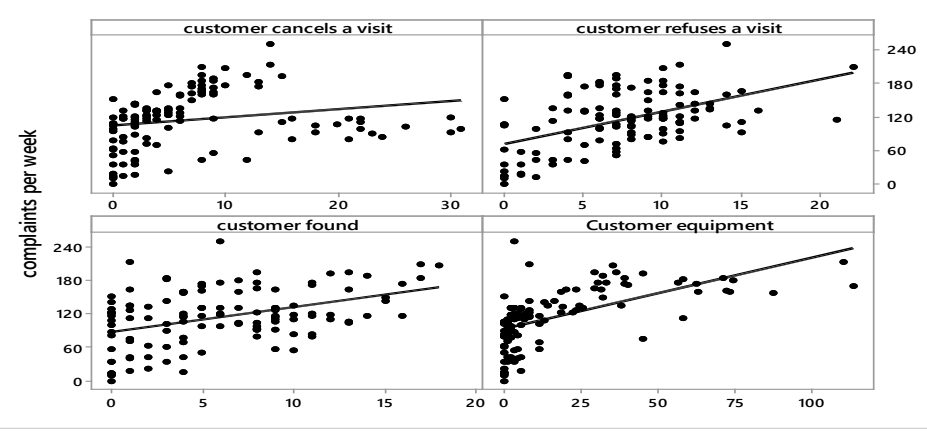

(b) Covariates associated with technical factors

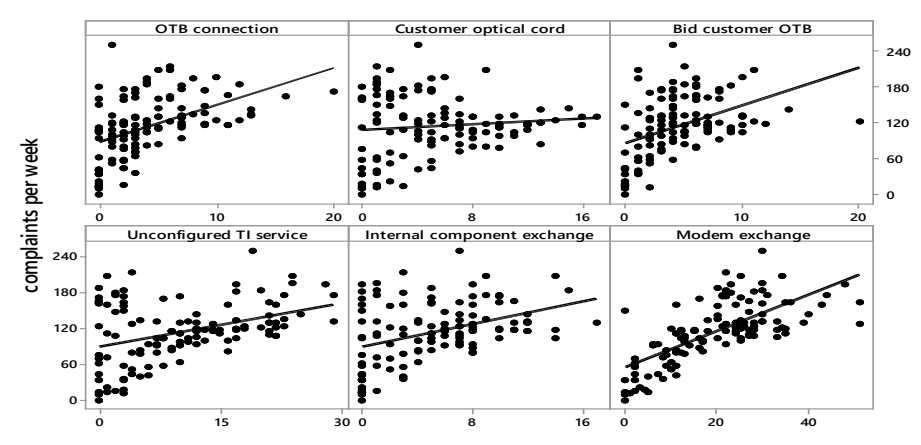

Figure 3: Dispersion diagrams

Initially, simple linear regression models (presence of only one covariate $\mathrm{x}$ ) in presence of linear and quadratic effects affecting the response (the choice of this model was based on the graphs presented in Figure 3, where linear effects and sometimes curvature effects are observed) are considered in the form,

$$
Y_{i}=\log (\text { complaint count })=\beta_{0}+\beta_{1} x_{i}+\beta_{2} x_{i}^{2}+\varepsilon_{i}
$$

The errors $\varepsilon_{\mathrm{i}}$ are assumed to be independent unobserved random variables with normal distribution $N\left(0, \sigma^{2}\right), i=1, \ldots, 117$. Associated with each case, we used hypothesis tests to verify whether the regression coefficients (linear effect and quadratic effect) $\beta_{1}$ and $\beta_{2}$ are statistically equal to zero. The needed assumptions (normality and constant variance for the errors) were verified using residual graphs. Using the Minitab ${ }^{\circledR}$ statistical software, the model fit (1) is obtained using least squares estimation methods to get the estimators of the regression parameters $\beta_{0}, \beta_{1}$ and $\beta_{2}$ considering the different covariates individually and the $\mathrm{p}$-values for each case. The significant covariates affecting the number of complaints are:

- Client covariates: client canceled a visit (linear and quadratic effects at a significance level of 5\%; p-value < 0.05); client refused to visit (linear and quadratic effects at a significance level of 5\%; p-value < 0.05); customer found with complaint (linear effect 
DOI: 10.14807/ijmp.v12i4.1352

at a significance level of 5\%; p-value < 0.05); (4) client equipment (linear and quadratic effects at a significance level of 5\%; p-value $<0.05$ ).

- Technical factors covariates: change of modem (linear and quadratic effects at a significance level of 5\%; p-value < 0.05); client optical cord (linear effect at a significance level of 5\%; p-value < 0.05); internal component exchange (linear and quadratic effects at a significance level of 5\%; p-value < 0.05); (4) unconfigured TI service (linear effect at a significance level of 5\%; p-value < 0.05); (5) customer OTB bid (linear and quadratic effects at a significance level of 5\%; p-value < 0.05); (6) OTB connection (linear and quadratic effects at a significance level of $5 \%$; p-value $<0.05$ ).

A second statistical analysis assumed a multiple linear regression model in the presence of all covariates (covariates associated with customers and technical covariates) and temporal covariates (months and years). The needed assumptions (normality and constant variance of the errors) were verified using residual graphs. Using the Minitab ${ }^{\circledR}$ statistical software, we have the following fitted model:

$\log ($ complaint number $))=208+0.00671$ customer.cancels.visit

$$
\begin{aligned}
& +0.0117 \text { customer.refuses.visit }+0.02642 \text { customer.found } \\
& +0.01233 \text { customer.equipment }+0.0105 \text { OTB.connection } \\
& +0.0054 \text { customer.optical.cord }+0.0168 \text { Bid.customer.OTB } \\
& +0.01405 \text { unconfigured.TI.service } \\
& +0.0229 \text { internal.component.exchange }+0.01668 \text { modem.exchange } \\
& \text { - } 0.102 \text { year }-0.0060 \text { month }
\end{aligned}
$$

From the obtained results, the covariates that are significatives, that is, the regression parameters associated with each covariate are statistically different of zero (p-value $<0.05$ ), are the customer found with complaints, customer equipment, modem exchange, exchange of internal component and TI configuration service.

\subsection{Use of a Poisson regression model for weekly complaint counts}

Another possibility in the analysis of the weekly complaint count data is to assume a Poisson regression model in the original scale (count). Poisson regression is a form of generalized linear model of regression analysis used to model count data (Montgomery \& Runger, 2011). Poisson regression models assume that the response variable $\mathrm{Y}$ has a Poisson 
DOI: 10.14807/ijmp.v12i4.1352

distribution and assumes that the logarithm of its expected value is modeled by a linear combination of unknown parameters. Let $Y_{i}$ (complaint count in the i-th week, $i=1,2, \ldots, 117$ ) denoting a random variable with a Poisson distribution,

$$
\mathrm{P}\left(\mathrm{Y}_{\mathrm{i}}=\mathrm{n}_{\mathrm{i}}\right)=\frac{\mu_{i}^{n_{i}} e^{-\mu_{i}}}{n_{i} !}
$$

where $n_{i}$ denotes the observed number of complaints in the $i$-th week, $n_{i}=0,1,2, \ldots . . ; i=1,2$, ..., 117. The mean and variance of the Poisson distribution (3) are equal to $\mu_{\mathrm{i}}$.

Associated with each week, it is assumed a regression model for the $\mu_{\mathrm{i}}$ parameter in the presence of the covariates customer cancels visit, customer refuses visit, customer found with different complaints, customer equipment, modem exchange count, client optic cord count, count internal component exchange, TI service count, customer OTB bid count, month and year, given by,

$\mu_{\mathrm{i}}=\exp \left\{\beta_{0}+\beta_{1}\right.$ customer.cancels.visit $_{\mathrm{i}}+\beta_{2}$ customer.refuses.visit $_{\mathrm{i}}+\beta_{3}$ customer.found $_{\mathrm{i}}$

$$
\begin{aligned}
& +\beta_{4} \text { Customer.equipment }_{i}+\beta_{5} \text { OTB.connection }_{i} \\
& +\beta_{6} \text { customer.optical.cord }_{i}+\beta_{7} \text { Bid.customer.OTB }_{i} \\
& +\beta_{8} \text { unconfigured.TI.service }_{i}+\beta_{\text {ginternal.component.exchange }}+ \\
& \left.+\beta_{10} \text { modem.exchange }_{i}+\beta_{11} \text { year }_{i}+\beta_{12} \text { month }_{i}\right\}
\end{aligned}
$$

We obtain the estimators of the regression parameters $\beta_{0}, \beta_{1}, \beta_{2}, \beta_{3}, \beta_{4}, \beta_{5}, \beta_{6}, \beta_{7}, \beta_{8}, \beta_{9}$, $\beta_{10}$ and $\beta_{11}$ using the maximum likelihood method (Montgomery \& Runger, 2011). From the obtained results (Table 3) using the Minitab ${ }^{\circledR}$ statistical software, the significative covariates, that is, with regression parameters associated with each covariate that are statistically different from zero (p-value < 0.05) are: client canceled visit , customer refuses to visit, customer found with complaint, customer equipment, modem exchange, internal component exchange, defaced TI service, customer OTB bid and month.

We observe that the Poisson regression model is more sensitive to detect the significant covariates affecting the company's weekly complaints counts. With these results, the company administrator has an excellent diagnosis of the technical services sectors that increase the complaints counts. Thus, several improvements and modifications will reduce the complaint counts.

The fitted regression model for the average number of complaints is given by, exp ( $\left.\mathrm{Y}^{\prime}\right)$ where, 
INDEPENDENT JOURNAL OF MANAGEMENT \& PRODUCTION (IJM\&P)

http://www.ijmp.jor.br

v. 12, n. 4, May-June 2021

ISSN: 2236-269X

DOI: $10.14807 /$ ijmp.v12i4.1352

$\mathrm{Y}^{\prime}=-63.1+0.00753$ customer cancels a visit +0.00572 customer refuses a visit

+0.01936 customer found +0.009055 Customer equipment +0.00481 OTB connection

+ 0.00516 Customer optical cord + 0.01413 Bid customer OTB

+ 0.01176 Unconfigured TI service + 0.01872 Internal component exchange

+0.01299 Modem exchange +0.0331 year +0.01101 month

We can get predictions from the fitted model (5). Figure 4 shows the graphs of the observed and predicted counts using model (5), indicating an excellent fit of the Poisson regression model to the data.

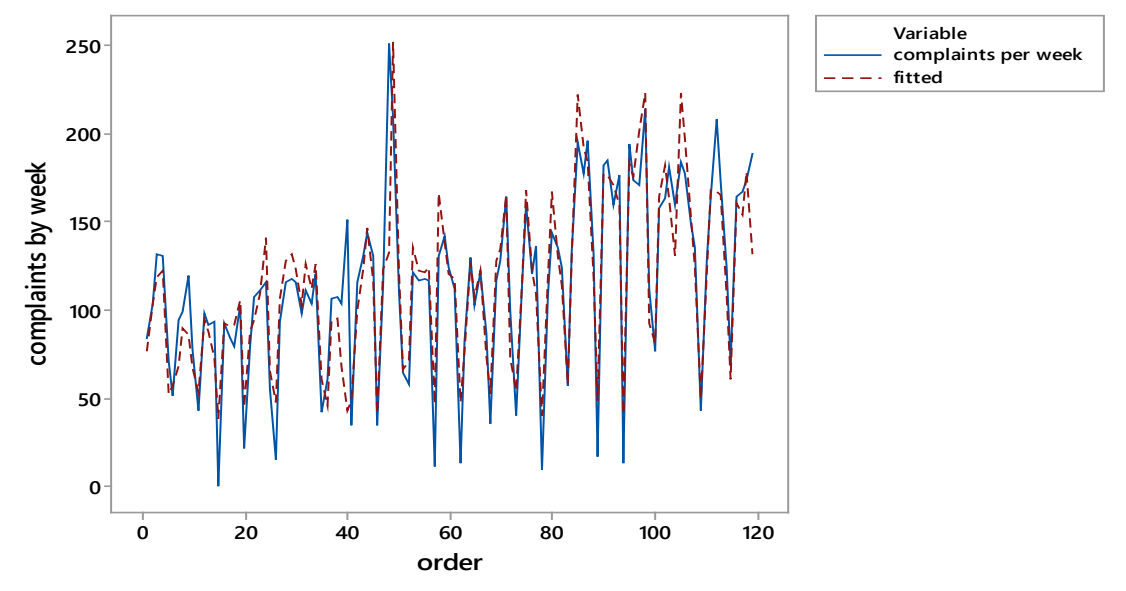

Figure 4: Graphs of observed counts and predicted by the model (5)

Table 3. Maximum likelihood estimators (MLE), standard errors of the estimators and pvalues (Poisson regression)

\begin{tabular}{|llll|}
\hline Parameter & MLE & SE & p-value \\
\hline Constant & -63.1 & 72.8 & \\
customer cancels visit & 0.00753 & 0.00147 & $<0.001$ \\
customer Refuses Visit & 0.00572 & 0.00263 & 0.030 \\
customer found & 0.01936 & 0.00225 & $<0.001$ \\
customer equipment & 0.00905 & 0.000481 & $<0.001$ \\
OTB conection & 0.00481 & 0.00279 & 0.085 \\
customer optical cord & 0.00516 & 0.00343 & 0.133 \\
customer OTB bid & 0.01413 & 0.00300 & $<0.001$ \\
defaced TI servisse & 0.01176 & 0.00147 & $<0.001$ \\
internal component exchange & 0.01872 & 0.00260 & $<0.001$ \\
Modem exchange & 0.01299 & 0.00116 & $<0.001$ \\
Year & 0.0331 & 0.0360 & 0.359 \\
Month & 0.01101 & 0.00343 & 0.001 \\
\hline
\end{tabular}

\section{DISCUSSION OF THE OBTAINED RESULTS AND CONCLUDING REMARKS}

The obtained results from the different statistical analyzes associated with the telephone company's complaint counts can be of great interest to the company. 
DOI: 10.14807/ijmp.v12i4.1352

The multiple linear regression models with normal errors with the responses (complaint counts transformed to the logarithmic scale) and the Poisson regression model can be used in predictions for complaint counts once the levels of the covariates have been fixed with a slight advantage for the Poisson regression model for discrete data without the need for transformations with direct interpretations for company administrators.

From the regression analysis, we discovered some factors that are affecting the time counts of complaints: customer canceled visit, customer refuses visit, customer found, customer equipment, modem exchange, internal component exchange, TI defaced service, bid customer OTB. These results can be of great interest to the telephone company.

It is important to point out that times series models as the moving average time series (MA) models and ARIMA models (Morettin \& Toloi, 1987; Box et al., 2015; Ho \& Xie, 1998; Akgun, 2003; Bell, 1984) are existing alternatives for the data analysis. These models should be build in each application, which can be an unfavorable point for the companies, despite leading to good forecasts.

Figure 5 shows the graphs for the observed and fitted time series by an ARIMA $(2,2,2)$ model using the Minitab ${ }^{\circledR}$ software. It is observed that there is similar fit using the ARIMA and the Poisson regression models (see Figure 4). A great advantage for the use of the regression models (linear multiple regression model for the number of complaints by week in logarithmic scale and the Poisson regression model) besides good fit, is the discovery of important factors that affect the response (number of complaints per week) that are of great interest for the company to improve its performance.

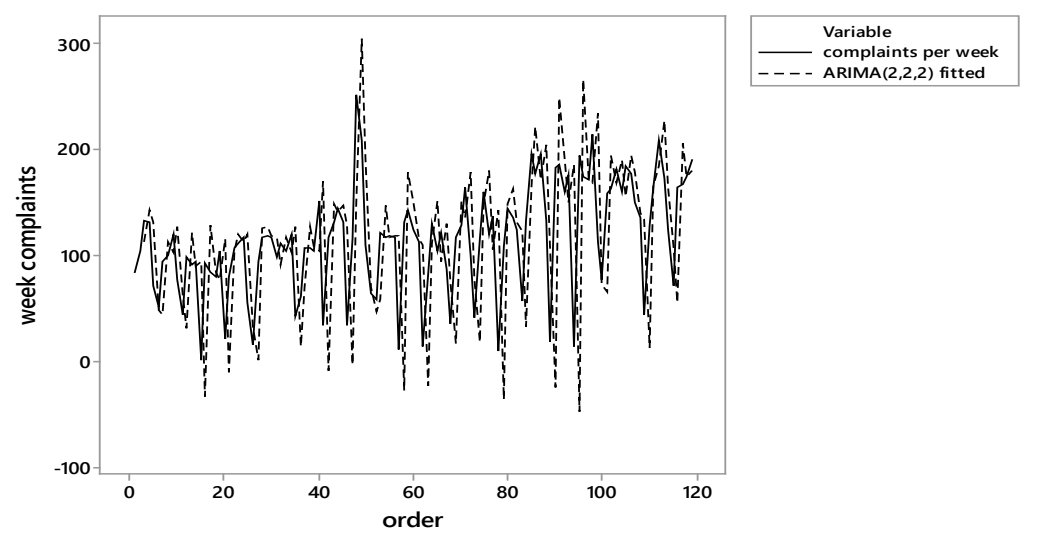

Figure 5: Graphs of the observed and fitted counts by the ARIMA (2, 2, 2) model

Another statistical analysis also was assumed using monthly compositional models (see Table 1 and Figure 1). Denoting \% complaints due to customers,\% complaints due to technical 
DOI: 10.14807/ijmp.v12i4.1352

problems and $\%$ complaints for other causes respectively for $\mathrm{x}_{1}, \mathrm{x}_{2}$ and $\mathrm{x}_{3}$, we have a restriction on the data $\mathrm{x}_{1}+\mathrm{x}_{2}+\mathrm{x}_{3}=1$, which makes it impossible to use the usual multivariate analysis techniques assuming a normal multivariate distribution (Johnson \& Wichern, 1998). Thus, an additive ratio log (LRA) transformation model proposed by Aitchison and Shen (1985) was considered given the responses given by $\mathrm{y}_{1 \mathrm{i}}=\log \left(\mathrm{x}_{1 \mathrm{i}} / \mathrm{x}_{3 \mathrm{i}}\right)$ and $\mathrm{y}_{2 \mathrm{i}}=\log \left(\mathrm{x}_{2 \mathrm{i}} / \mathrm{x}_{3 \mathrm{i}}\right)$, and the following regression models,

$Y_{\mathrm{ji}}=\beta_{0 \mathrm{j}}+\beta_{1 \mathrm{j}}$ customer.cancels.visit $t_{\mathrm{i}}+\beta_{2 \mathrm{j}}$ customer.refuses.visit ${ }_{\mathrm{i}}+\beta_{3 \mathrm{j}}$ customer.found $_{\mathrm{i}}$

$+\beta_{4 j}$ customer.equipment $t_{i}+\beta_{5 j}$ OTB.connection ${ }_{i}$

$+\beta_{6 j}$ customer.optical.cord ${ }_{i}+\beta_{7 j}$ Bid.customer.OTB $i$

$+\beta_{8 j}$ unconfigured.TI.service $+\beta_{9 j}$ internal.component.exchange ${ }_{i}+$

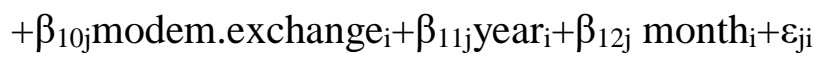

where $\mathrm{j}=1,2$; $\varepsilon_{\mathrm{ji}}$ are assumed independent errors with normal distributions $\mathrm{N}\left(0, \sigma_{\mathrm{j}}^{2}\right)$ for $\mathrm{j}=1$, 2.

Associated with model (6), the following covariates were found (using the Minitab ${ }^{\circledR}$ software) as significatives (p-value $<0.05$ ) in response $\mathrm{y}_{11}$ : client canceled visit, client refused visit, found with complaint, client equipment, connection OTB, customer's optical cord, unconfigured TI service and modem exchange. Likewise, the following covariates were found to be significatives in the $\mathrm{y}_{2 i}$ response ( $\mathrm{p}$-value $<0.05$ ): customer canceled visit, found with complaint, customer's equipment, unconfigured TI service, internal component exchange and modem exchange. Thus, we have significative covariates similar to those found in the multiple linear regression analysis assuming transformed responses in the logarithmic scale.

\section{REFERENCES}

Aitchinson, J., \& Shen, S. M. (1985). Logistic-normal distributions: Some properties and uses. Biometrika, 47, 136-146.

Akgun, B. (2003). Identification of periodic autoregressive moving average models. $\mathrm{PhD}$ thesis. Dept. of Statistics, Middle East Technical University, Turkey.

Albrecht, K., \& Bradford, L. J. (1992). Serviço com qualidade: a vantage competitiva. São Paulo: Makron Books.

Anderson, E. W., Fornell, C., \& Mazvancheryl, S. K. (2004). Customer satisfaction and shareholder value. Journal of Marketing, 68(4), 172-185.

Bell, W. R. (1984). An introduction to forecasting with time series models. Insurance: Mathematics and Economics, 3(4), 241-255. 
Box, G. E., Jenkins, G. M., Reinsel, G. C., \& Ljung, G. M. (2015). Time series analysis: forecasting and control. John Wiley \& Sons.

Carvalho, M., \& Paladini, E. P. (2005). Gestão da Qualidade: teoria e casos. 2. ed. Rio de Janeiro: Elsevier.

Chevalier, J. A., \& Mayzlin, D. (2006). The effect of word of mouth on sales: online book reviews. Journal of Marketing Research, 43(3), 345-354.

DOI: 10.1509/jmkr.43.3.345.

Chiavenato, I. (2007). Empreendedorismo: dando asas ao espirito empreendedor. São Paulo: Saraiva.

Claro, D._P., Fragoso, A. F. G. R., Laban Neto, S. A., \& Claro, P. B. O. (2014). Consumer Complaints and Company Market Value. Brazilian Administration Review, 11(3), 248-263. DOI: http://dx.doi.org/10.1590/1807-7692bar2014130004.

Coelho, B. R. G., Queiroz, V. G., Calazans, C. H. J., \& Silva, R. L. K. (2016). A consolidação de sites de reclamação online como uma alternativa eficaz no intermédio das relações de consumo: um estudo de caso do site Reclame Aqui. Anais do Congresso de Ciências da Comunicação na Região Nordeste, Caruaru, PE, Brasil, 18

Fornell, C., \& Wernerfelt, B. (1987). Defensive Marketing Strategy by Customer Complaint Management: A Theoretical Analysis, Journal of Marketing Research, 24(4), 337-346.

Gimenes, R. M. T. et al. (2013). Aplicação do controle estatístico de processo em uma empresa do setor avícola. Revista de Administração e Inovação, São Paulo, 10(4), 38-62.

Goldenberg, J., Libai, B., Moldovan, S., \& Muller, E. (2007). The NPV of bad news. International Journal of Research in Marketing, 24(3), 186-200.

DOI: 10.1016/j.ijresmar.2007.02.003

Ho, S., \& Xie, M. (1998). The use of ARIMA models for reliability forecasting and analysis. Computers and Industrial Engineering, 35(1-2), 213-216.

Johnson, R., \& Wichern, D. (1982). Applied multivariate statistical analysis. New Jersey: Prentice Hall.

Kotler, P., \& Armstrong, G. (2003). Princípios de Marketing. 9. ed. São Paulo: Prentice Hall.

Kotler, P. (1998). Administração de marketing: análise, planejamento, implementação e controle. 5. ed. São Paulo: Atlas.

Luo, X. (2007). Consumer negative voice and firm-idiosyncratic stock returns. Journal of Marketing, 71(3), 75-88. DOI: 10.1509/jmkg.71.3.75

Luo, X. (2009). Quantifying the long-term impact of negative word of mouth on cash flows and stock prices. Marketing Science, 28(1), 148-165. DOI: 10.1287/mksc.1080.0389

Mahfood, P. E. (1994). Transformando um cliente insatisfeito em um cliente para sempre. São Paulo: Makron Books.

Martins, B., C., \& Julio, G., N. (2013). A ascensão ou queda de uma marca nas mãos do novo consumidor: um estudo de caso da Americanas.com. Revista de Administração e Negócios da Amazônia, 5(2), 1-1. 
Matos, C. A., \& Rossi, C. A. V. (2008). Word-of-mouth communications in marketing: a meta-analytic review of the antecedents and moderators. Journal of the Academy of Marketing Science, 36(4), 578-596.

Melo, C. A. D. et al. (2019). O controle estatístico de processos no monitoramento da fabricação em uma empresa no ramo colchoeiro. Brazilian Journal of Developing, 5(12), 29165-29185.

Mittal, V., Ross, W. T., \& Baldasare, P. M. (1998). The asymmetric impact of negative and positive attribute-level performance on overall satisfaction and repurchase intentions.

Journal of Marketing, 62(1), 33-47.

Montgomery, D. C. (2012). Introdução ao Controle Estatístico da Qualidade. $4^{\text {th }}$ ed, Rio de Janeiro: LTC.

Montgomery, D. C., \& Runger, G. C. (2011). Applied statistics and probability for engineers. New York: Wiley.

Morettin, P. A., \& Toloi, C. M. (1987). Previsão de séries temporais. $2^{\text {th }}$ ed. São Paulo: Atual.

Pimentel, R. C., \& Aguiar, A. B. (2012). Persistência de lucros trimestrais: uma investigação empírica no Brasil. Brazilian Business Review, 9, 39-57.

Portaluppi, J., Heinzmann, L. M., Tagliapietra, O. M., \& Borilli, S. P. (2006). Análise do atendimento e satisfação dos clientes: Estudo de caso de uma empresa de insumos agrícolas. Revista de Ciências Empresariais da UNIPAR, Umuarama, 7(1), 75-91. DOI: https://doi.org/10.25110/receu.v7i1.520

Richins, M. L. (1983). Negative word-of-mouth by dissatisfied consumers: a pilot study. Journal of Marketing, 47(1), 68-78.

Romani, S., Grappi, S., \& Dalli, D. (2012). Emotions that drive consumers away from brands: measuring negative emotions toward brands and their behavioral effects.

International Journal of Research in Marketing, 29(1), 55-67.DOI:

10.1016/j.ijresmar.2011.07.001

Singh, J., \& Wilkes, R. E. (1996). When consumers complain: a path analysis of the key antecedents of consumer complaint response estimates. Journal of the Academy of Marketing Science, 24(4), 350-365.

Singh, J (1988). Consumer complaint intentions and behavior: definitional and taxonomical issues. Journal of Marketing, 52(1), 93-107.

Sousa, F. J. S. F. (2011). Satisfação de Clientes - O Caso de Uma Empresa Industrial, Dissertação de Mestrado em Marketing, Faculdade de Economia da Universidade de Coimbra, Portugal.

Trusov, M., Bucklin, R. E., \& Pauwels, K. (2009). Effects of word-of-mouth versus traditional marketing: findings from an internet social networking site. Journal of Marketing, 73(5), 90-102. DOI: 10.1509/jmkg.73.5.90.

Winchester, M., Romaniuk, J., \& Bogomolova, S. (2008). Positive and negative brand beliefs and brand defection/uptake. European Journal of Marketing, 42(5/6), 553-570. DOI: $10.1108 / 03090560810862507$. 